\title{
Correction to: Covariance structure analysis in experimental research: Comparing two word translation models
}

\author{
Janet G. Van Hell ${ }^{1} \cdot$ Paul Oosterveld $^{1}$ - Annette M. B. De Groot ${ }^{1}$ \\ Published online: 26 April 2021 \\ (C) The Psychonomic Society, Inc. 2020
}

\section{Correction to: Behav Res https://doi.org/10.3758/BF03200538}

In the online pdf of this paper, a page was missing. It has been corrected online.

Publisher's note Springer Nature remains neutral with regard to jurisdictional claims in published maps and institutional affiliations.

The online version of the original article can be found at https://oi.org/ 10.3758/BF03200538

Janet G. Van Hell

pn_hell@macmail.psy.uva.nl

1 Department of Psychology, University of Amsterdam, Roetersstraat 15, 1018 WB Amsterdam, The Netherlands 